\title{
The Uniqueness of STAD and CIRC Models in Poetry Learning (Keunikan Model STAD dan CIRC dalam Pembelajaran Puisi)
}

\author{
Diyan Permata Yanda ${ }^{\mathrm{a}, \mathrm{b}, 1}$, Dina Ramadhanti ${ }^{\mathrm{a}, 2}$ \\ ${ }^{a}$ IAIN Bukittinggi, Indonesia \\ b STKIP PGRI Sumatera Barat, Indonesia \\ 1diyan_yanda@yahoo.com; ${ }^{2}$ dina_ramadhanti89@yahoo.com
}

\begin{tabular}{ll}
\hline Article info & A B S T R A C T \\
\hline Article history: & The purpose of this study is to describe the uniqueness of the \\
Revised : 23-02-2020 & Student Team Achievement Division (STAD) and Cooperative \\
Accepted:17-04-2021 & Integrated Reading and Composition (CIRC) models in terms of \\
& poetry learning. This is a quantitative study that uses a pure \\
& experimental method. The randomized posttest in the control \\
& group was used as the experimental design. With the average \\
& similarity test, the study sample was chosen randomly, class of \\
& Experiment I and Experiment II. The STAD model was used to \\
& teach poetry to experimental class I, and the CIRC model was \\
& used to teach poetry to experimental class II. Both learning \\
& models can be employed in poetry learning, according to the \\
& findings, because they improve poetry understanding skills, \\
& social skills in terms of interpreting poetry content, and the \\
& process and ultimate outcomes of poetry learning. Both types \\
& have their own distinct characteristics that make them suited for \\
& poetry instruction. The STAD model differs from others in that it \\
& creates opportunities for students to collaborate in groups, take \\
& responsibility, and high abilities. The CIRC model is unique in \\
that it divides students into groups according to their level of \\
reading interest, collaborate and encourage one another.
\end{tabular}

Keywords:

$S T A D$

CIRC

Poetry Learning
Penelitian ini bertujuan untuk mendeskripsikan keunikan Model STAD (Student Team Achievement Division) dan CIRC (Cooperative Integrated Reading and Composition) dalam pembelajaran puisi. Jenis penelitian ini adalah kuantitatif dengan metode eksperimen murni. Desain eksperimen yang digunakan adalah the randomized posttest only control group design. Sampel penelitian dipilih secara random dengan uji kesamaan rata-rata, yakni kelas Eksperimen I dan Eksperimen II. Kelas eksperimen I menerima pengajaran puisi dengan model STAD dan kelas eksperimen II menerima pengajaran puisi dengan model CIRC. Hasil penelitian menunjukkan bahwa kedua model pembelajaran dapat digunakan dalam pembelajaran puisi karena memberi dampak pada peningkatan keterampilan memahami puisi, peningkatan kemampuan sosial dalam hal memaknai isi puisi, dan peningkatan proses dan hasil belajar puisi secara keseluruhan. Keunikan model STAD adalah pemberian reward yang memberikan dorongan kepada mahasiswa untuk berkolaborasi kelompok, bertanggung, dan pendampingan agar kemampuan kelompok merata. Keunikan model CIRC adalah pembagian kelompok yang didasarkan pada tinggi rendahnya minat baca mahasiswa, bekerja sama, dan saling memotivasi.

Copyright $(\odot 2021$ Institut Agama Islam Negeri Syekh Nurjati Cirebon.

\section{INTRODUCTION}

Understanding poetry is an important aspect of appreciating poetry in literary activities. Poetry appreciation can be defined as an attempt to recognize poetry and 
to be sensitive to all parts of poetry so that one can consciously enjoy and evaluate poetry. This poetry appreciation activity must be carried out in such a way that the reader not only understands but also appreciates the poetry that has been read. The appreciation activity consists of five stages, namely perception, knowledge, understanding, analysis, and assessmen. Students can gain the exercise of understanding poetry by taking the Poetry Appreciation course. This course is registered in the Indonesian Language and Literature Study Program of STKIP PGRI in West Sumatra with the code BIND8022. Theoretical approaches to poetry are introduced in this course. After learning about poetry theories, students can use poetry appreciation exercises to evaluate the poems they have read.

Understanding poetry is one of the levels of poetry appreciation that students should be familiar with (Mulyaningsih, 2015). Comprehension is the process by which a listener or reader interprets a set of words or writing, which is subsequently referred to as the compilation process. Understanding poetry necessitates an understanding of poetry. The inner structure and physical structure of a poem can both be used to determine its existence. Themes, tastes, tones, and messages are all part of the inner structure. Appearance, pictures, concrete words, metaphorical language, and verification are all part of the physical structure. Reading comprehension skills are essential to understand the structure of poetry. The ability to appreciate poetry is highly influenced by a strong reading interest. The ability to understand the physical structure of poetry is influenced by attention to reading, whereas the ability to understand the inner structure of poetry is influenced by feelings and responses to reading.

As part of poetry appreciation activities, poetry learning has not been conducted with the goal of raising students' reading interest or enabling them to understand the structure of poetry. Preliminary investigations based on observation activities suggest that students learn poetry through the processes of completing a reading report on the lecture material of Poetry Appreciation and then participating in discussions based on the reading reports completed by students. A test of comprehending the results of learning to interpret poetry is provided to students to test their understanding. The typical student learning results in poetry comprehension ranged from 30 to 50 percent. The process and student learning outcomes have not improved as a result of poetry learning. The reading reports that are written are usually similar and are just theoretical copies of the reference books that students utilize. Not all students actively participated in expressing their thoughts during group discussions.

This demonstrates that teachers must select a learning model that will encourage students to participate actively in their studies. Students participate in group discussions solely to follow the processes used by lecturers during presentations, not to improve their grasp of the content. As a result, teachers must employ a cooperative learning paradigm that not only emphasizes student-centered learning but also assumes increased student collaboration in order to comprehend cooperative learning. The cooperative model used in this study is the type of Student Team Achievement Division (STAD) and Cooperative Integrated Reading and Composition (CIRC). The STAD model is executed by the teacher splitting students into heterogeneous groups to discuss learning materials, compete with other groups for scores, and completing individual examinations to assess understanding of group activities. The CIRC model is implemented in study groups by combining reading and writing. Learning with the STAD and CIRC models is distinctive from 
what has been done previously with discussion methods. Both of these learning models strive to get everyone in the group involved in the learning process. The STAD and CIRC models will reveal which group is actually performing the task and helping their peers through learning activities.

According to previous studies, the STAD model is frequently implemented in learning for a wide range of mathematical subjects, problems (Sepriyanti et al., 2019), language complexities to develop writing skills (Thresia, 2012), reading comprehension (Syafiq \& Rahmawati, 2017; Primasari, 2018; Ugwu, 2019; Nurhuda, 2020), and student motivation to develop speaking skills (Afrinda \& Yanda, 2019; Firnanda et al., 2019). The STAD model can improve student achievement, attitudes, and teamwork in heterogeneous groups (Jamaludin \& Mokhtar, 2018; Syahidi, Asyikin, \& Asy'ari, 2018; Garcha, 2019; Yuliani, 2019). It is evident in the learning paradigm, which may be used to solve a variety of learning difficulties and subjects independent of gender, ethnicity, race, religion, and social status (Eneogu et al., 2019).

Likewise, the CIRC model has been utilized in a variety of learning situations. To promote reading comprehension, the CIRC model is applied (Zainuddin, 2015; Martono, Purwanti, Syukri, \& Soeharto, 2019) in writing various texts, such as narrative text, explanatory text (Qamariah et al., 2019), exposition text (Nafisah, 2018), and essays (Khuzaemah \& Herawati, 2017). The CIRC model is deemed to be capable of increasing student motivation to learn to read and write.

Previous research has largely come to the same conclusions about the efficiency of the STAD and CIRC models in terms of improving learning outcomes. These conclusions are offered in order to highlight the benefits of each learning model. The study's conclusion just states that the two models are successful in various levels of education and branches of science, but not at what point the models help students learn effectively.

In this study, the STAD and CIRC models will be used to teach poetry. This study intends to discover the uniqueness of each of these models in learning poetry, especially for students of the Indonesian Language Education and Literature Study Program, STKIP PGRI in West Sumatera, Indonesia, in addition to determining the efficiency of the two models in learning poetry. Finally, this research will address two research questions: how do the STAD and CIRC models influence poetry learning, and what is the uniqueness of the STAD and CIRC models that is thought to boost students' poetry learning abilities.

\section{METHOD}

The design of this study is an experimental study with a randomized posttest in the control group. This study lasted six weeks, from February 6 to March 18, 2017. The research participants were students from class 2016, who were divided into four sessions: A, B, C, and D. The research subjects were chosen at random using simple techniques. The stages of determining the research subject were: (1) collecting the initial test scores of understanding poetry, (2) conducting the average similarity test by performing the normality and homogeneity tests in each class, and (3) conducting the analysis requirements test by selecting two distributed normal classes and homegeneity on the mean of a similarity test. In this process, session B and session $\mathrm{C}$ were selected as research subjects.

There were two tools employed in this study: SAP and multiple-choice tests to understand poetry. The steps of the STAD and CIRC models are used to prepare 
SAP. SAP is validated by teaching experts before being used. SAP is graded on four criteria: content, language, presentation, and graphics. The validation results suggest that SAPs organized by STAD model stages are in the good category, with an average of 4.20. With an average of 4.30, SAPs created according to the steps of the CIRC model are categorized as good.

Table 1.

The STAD and CIRC Models Procedures in Learning Poetry

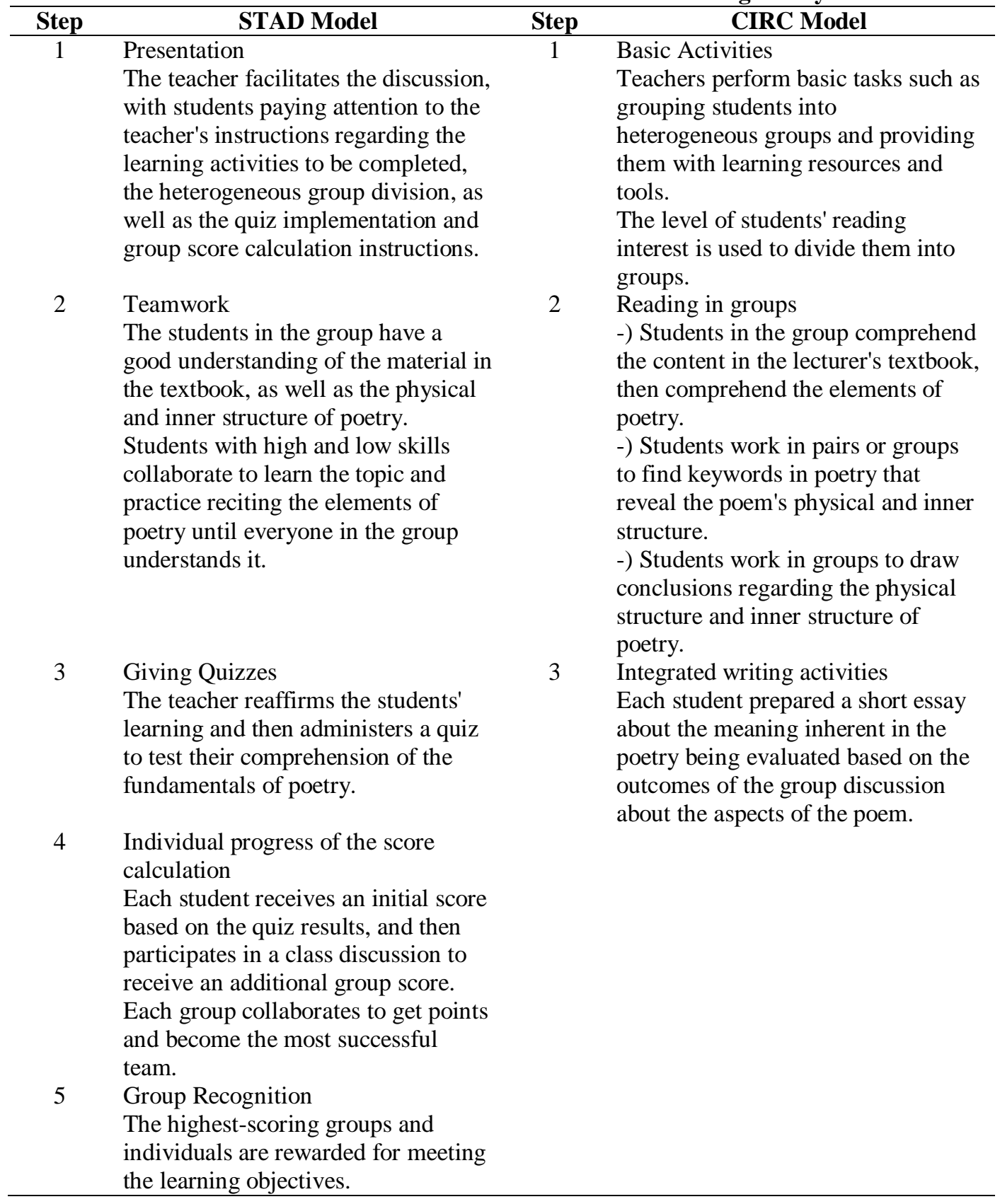

Apart from SAP, a multiple-choice test was also developed to measure students' grasp of poetry. Experts validated the test instrument in terms of instructions, coverage, and language before they were utilized. Expert validation revealed that the test instrument was rated as good, with an average score of 4.60. Item validation was done in conjunction with content validation. The validity and 
reliability of the test were tested as part of item validation. Of the 65 items tested, the remaining 50 items were suitable for the data collection.

In session $\mathrm{B}$, teachers use the STAD model to teach poetry, and in session $\mathrm{C}$, they use the CIRC model to teach poetry. The teacher provided a posttest to the two experimental classes to test each student's understanding of poetry after teaching them to interpret poetry using the STAD model and the CIRC model respectively. Table 1 depicts the STAD and CIRC model procedures for learning poetry in the two experimental classrooms.

Students in both experimental groups were given books on comprehending poetry, including physical and mental structure (Ramadhanti \& Yanda, 2017). Students were given a multiple-choice test to measure their grasp of poetry after the process of comprehending poetry in both experimental classes ended.

The $t$-paired sample test formula was used to quantify student learning outcomes in both experimental groups, and one-way ANOVA testing was used to determine the difference in scores between the experimental and control groups. With a significance level of 5\%, this study uses the Liliefors test to assess the normality of the data and the Barlet test to check the homogeneity of the data.

\section{RESULTS AND DISCUSSION}

The goal of this research is to answer two questions: how do the STAD and CIRC models influence poetry learning, and what makes the STAD and CIRC models unique in poetry learning.

\section{Poetry Learning Outcomes and the STAD Model}

The following information was obtained from data analysis on learning outcomes to understand poetry using the STAD model: the highest score was 88.00; the lowest value was 58.00; mean 75.48; standard deviation 9,10; 83.00 mode; and a median of 81.88 . Table 2 illustrates the frequency distribution of these findings.

Table 2.

A Data Frequency Distribution of Learning Outcomes in Experiment Class I

\begin{tabular}{|c|c|c|c|c|c|}
\hline Data & $\operatorname{Mean}(\widehat{X})$ & Frequency & $X_{i}^{2}$ & $F i X i$ & $F_{i} X_{i}^{2}$ \\
\hline $58-62$ & 60 & 3 & 3600 & 180 & 10800 \\
\hline $63-67$ & 65 & 5 & 4225 & 325 & 21125 \\
\hline $68-72$ & 70 & 5 & 4900 & 350 & 24500 \\
\hline $73-77$ & 75 & 0 & 5625 & 0 & 0 \\
\hline $78-82$ & 80 & 8 & 6400 & 640 & 51200 \\
\hline $83-88$ & 85,5 & 9 & 7310,25 & 769,5 & 65792,25 \\
\hline \multicolumn{2}{|c|}{ Total } & $\sum F=30$ & & $=2264,5$ & $\sum_{=173417,25} F_{i} X_{i}^{2}$ \\
\hline
\end{tabular}

Figure 1 depicts the frequency distribution of student learning outcomes data using the STAD model. 


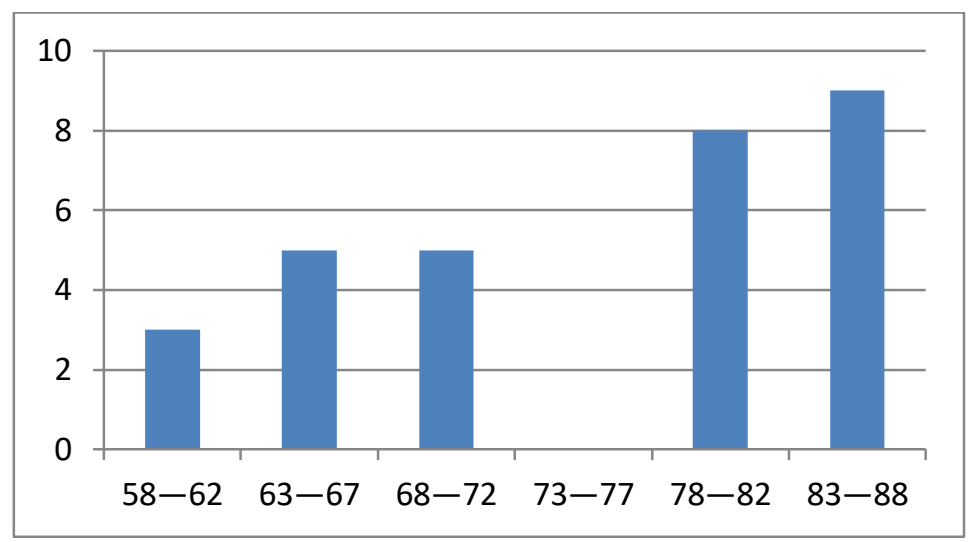

Figure 1.

A diagram illustrating the results of adopting the STAD Model to understand poetry.

The STAD model greatly improved student learning outcomes before and after it was implemented. Prior to the implementation of the STAD model, student learning outcomes ranged from 30 to 50 percent. Student learning outcomes improved by 58-88 percent, with a mean of 75.48 percent, after applying the STAD model. These findings also suggest that STAD has evolved into a learning model capable of influencing poetry learning. This result is also inextricably linked to the teacher's role in efficiently implementing each level of the STAD model. When the STAD model is used correctly, it can boost student engagement in classroom learning since they are required to perform at their best in groups in order to become the best team (Nurhuda, 2020). Students with high abilities in study groups must assist students with poor skills in understanding how to learn collaboratively. To be the best team, each group's abilities must be evenly distributed. Each member of the group must participate actively in group activities and class discussions. Groups that are able to work together well to complete each level of learning poetry will receive high marks. Furthermore, in order to receive the teacher's award, each group must be able to accumulate the highest points. This is congruent with the STAD model, which uses incentives or prizes to encourage and improve team collaboration (Lantajo \& Tipolo, 2019). Teachers who apply the STAD model in the classroom will considerably assist students in increasing motivation, cooperation, helping one another, and asking group questions (Erly, 2020). In addition, this model is also known as a student-centered learning model because it encourages students to understand learning, develop their abilities to express opinions, discipline themselves, and take more responsibility for themselves and their groups at each step of learning (Dewi et al., 2020).

\section{Poetry Learning Outcomes and the CIRC Model}

The following information was gathered from data analysis on learning outcomes to interpret poetry using the CIRC model: the maximum score was 92.00 ; the lowest score was 54.00; mean 73.50; standard deviation 12.37; mode 86.88; and median 93.16. Table 3 illustrates the frequency distribution of these findings. 
Table 3.

A Data Frequency Distribution of Learning Outcomes in Experiment Class II

\begin{tabular}{crrrrr}
\hline Data & Mean $(\widehat{\boldsymbol{X}})$ & \multicolumn{1}{c}{ Frequency } & \multicolumn{1}{c}{$\boldsymbol{X}_{\boldsymbol{i}}$} & $\boldsymbol{F i \boldsymbol { i }}$ & $\boldsymbol{F}_{\boldsymbol{i}} \boldsymbol{X}_{\boldsymbol{i}}{ }^{\mathbf{2}}$ \\
\hline $54-60$ & 57 & 6 & 3249 & 342 & 19494 \\
$61-67$ & 64 & 6 & 4096 & 384 & 24576 \\
$68-74$ & 71 & 3 & 5041 & 213 & 15123 \\
$75-81$ & 78 & 2 & 6084 & 156 & 12168 \\
$82-88$ & 85 & 7 & 7225 & 595 & 50576 \\
$89-95$ & 92 & 4 & 8464 & 368 & 33856 \\
& Total & & $\sum \boldsymbol{F}=\mathbf{2 8}$ & & $\sum \boldsymbol{F}_{\boldsymbol{i}} \boldsymbol{X}_{\boldsymbol{i}}=\mathbf{2 0 5 8} \quad \sum \boldsymbol{F}_{\boldsymbol{i}} \boldsymbol{X}_{\boldsymbol{i}}{ }^{2}=\mathbf{1 5 5 7 9 3}$ \\
\hline
\end{tabular}

Figure 2 depicts the frequency distribution of student learning outcomes data using the CIRC model.

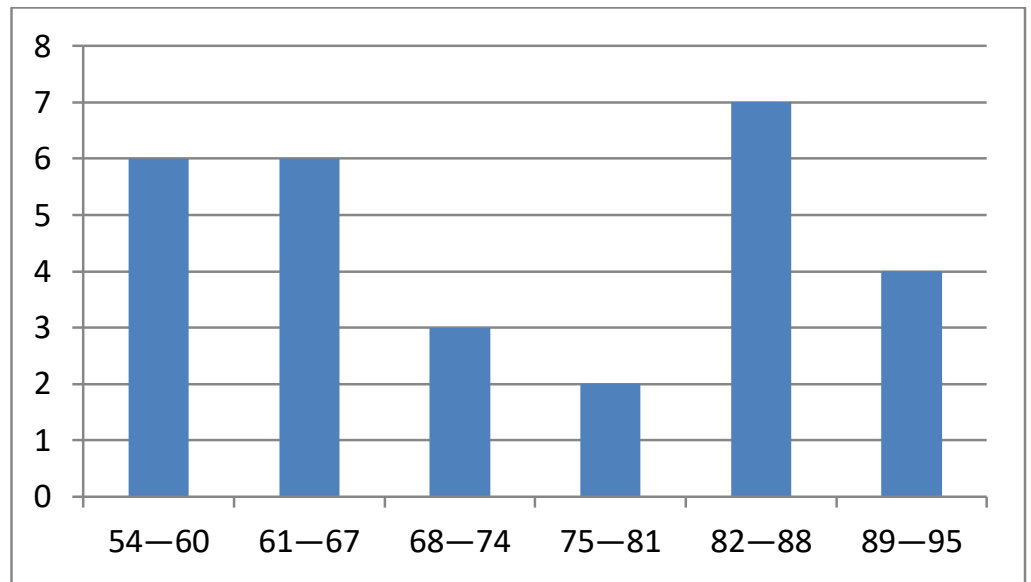

Figure 2.

A diagram depicting the results of utilizing the CIRC Model to understand poetry.

Before and after utilizing the CIRC model, student learning results improved dramatically. Prior to the implementation of the STAD model, student learning outcomes ranged from 30 to 50 percent. Student learning outcomes improved by 54-92 percent after applying the STAD model, with a mean of 73.50 percent. These findings suggest that CIRC has had an impact on poetry learning. Students' efforts to comprehend poetry learning have been influenced by the division of groups based on their level of interest in reading. Students with a strong interest in reading assist students with a weak interest in reading so that they can work together to comprehend the structure of poetry. Students who have a low reading interest are encouraged to develop their reading interest by students who have a high reading interest.

There are some learning stages that require students to read and correct each other if reading comprehension mistakes are discovered. This practice encourages students who have a low reading interest to develop their reading interest so that they can read comprehension with students who have a high reading interest. Reading interest is a factor that impacts the ability to appreciate poetry, especially when learning to understand it (Ramadhanti \& Yanda, 2020). They also collaborate to compose their collaborative outputs as short essays in an attempt to comprehend the poetry's substance. This is in line with prior study, which found that CIRC can 
encourage students who have a strong interest in reading to collaborate and exchange ideas with students who have a weak interest in reading, so increasing their desire and drive to learn to read (Astuti, 2014). Because CIRC is also considered as a learning model that is particularly successful in learning to write, students simultaneously write their collaborative outcomes in writing after studying the reading (Parmawati, 2015). This is in line with the CIRC model's main principle, which incorporates reading and writing in a seamless manner throughout the learning stages.

\section{The Uniqueness of STAD and CIRC Models In Poetry Learning}

It is crucial to test the hypothesis before explaining the uniqueness of the STAD and CIRC models in poetry learning. Hypothesis testing also seeks to discover whether the two experimental classes have different learning results. The analysis requirements test, which combines a data normality test and a data homogeneity test, is performed prior to evaluating the hypothesis. The findings of the data normality test revealed that L0 of 0.159 and Lt of 0.161 were achieved for the experimental class I at alpha $(\alpha)$ 0.05, whereas L0 of 0.198 and Lt of 0.161 were obtained for the experimental class II at alpha $(\alpha) 0.05$. If L0 $<\mathrm{Lt}$, data is normally distributed. The experimental group I had normally distributed data, whereas the experimental class II contained non-normally distributed data. These findings also show that students' abilities in experimental class I were evenly distributed, whereas students' abilities in experimental class II were not. Furthermore, the F-count was 1.788 and the F-table was 1.85 for the data homogeneity test at alpha $(\alpha) 0.05$. Because of F-count and F-table, the variances of experimental groups I and II seem to be the same.

The analysis requirements test reveals that one of the experimental classes is not normally distributed, but that the variances of both are homogeneous. Table 4 presents the hypothesis test calculations.

Table 4.

Hypothesis Test

\begin{tabular}{ccccccc}
\hline Groups & $\mathbf{N}$ & $\overline{\boldsymbol{X}}$ & $\mathbf{S}$ & $\boldsymbol{S}^{\mathbf{2}}$ & $\mathbf{t}_{\text {count }}$ & $\mathbf{t}_{\text {table }}$ \\
\hline Experimental & 30 & 75,48 & 9,10 & 82,81 & & \\
Group I (STAD) & & & & & 0,678 & 1,67 \\
Experimental & 29 & 73,5 & 12,71 & 161,54 & & \\
Group II (CIRC) & & & & & \\
\hline
\end{tabular}

Table 4 shows that the $t$-count is 0.678 and the $t$-table is 1.67 at alpha $(\alpha) 0.05$. If $\mathrm{t}$-count $>\mathrm{t}$-table, the hypothesis is accepted. The hypothesis test revealed that there was no significant difference in learning results when utilizing the STAD and CIRC models to understand students' poems. The findings of the hypothesis test demonstrate that there is no significant difference in learning outcomes between the two groups. This is also evidenced by the fact that the mean learning outcomes in the two experimental groups were not significantly different. In the two experimental groups, the mean difference in learning results for understanding poetry was roughly 1.98 .

In the process of learning to interpret poetry, the two learning models are effectively applied. These findings also suggest that the two learning models are distinct enough to be used in poetry teaching. Both learning models are equally effective in the study of poetry. Students will learn to grasp poetry if they fully comprehend the poetry presented by the teacher. The STAD and CIRC models have 
aided students in their quest to comprehend all aspects of poetry. Students must be able to describe not just the physical form of poetry, but also the inner structure of poetry in order to interpret poetry using their intuition.

The STAD and CIRC models can be used to better understand poetry as part of poetry appreciation activities. Both strategies enable students to engage in a meaningful learning experience. Meaningful learning, especially poetry, can assist students form and find new knowledge from the learning process, affecting their desire and aptitude to study. (Rahayu et al., 2018). Student enthusiasm in learning poetry will grow when the teacher provides poetry with subjects that are relevant to students, such as character education (Ulya et al., 2016) and the use of a specific model to accomplish learning achievements integrated with components of local wisdom. Teachers may teach poetry that is relevant to their students' social environments, allowing them to understand poetry more sensitively. As a result, students may appreciate poetry based on what they comprehend in their daily lives, rather than only intellectually understanding it. This might motivate them to use the STAD and CIRC learning models.

In the learning process, both the STAD and CIRC models are equally successful. Because each stage enables students to improve their comprehension through activities that increase learning motivation, the STAD model is particularly helpful in the learning process to grasp poetry (Yanda, 2018). STAD integrates and fosters student creativity through connectivity and direct collaboration, empowering students to study in an enjoyable way (Jamaludin \& Mokhtar, 2018) while CIRC places a strong emphasis on reading comprehension and writing down what has been acquired. Each student is encouraged to enhance their reading comprehension skills through this practice. Furthermore, students' enthusiasm for reading and their ability to comprehend poetry elements will have an impact on other aspects of poetry appreciation, such as writing poetry (Sari \& Yanda, 2016). Because of the teamwork involved in completing tasks, students who have a limited interest in reading will be driven to participate in the learning process (Ramadhanti \& Yanda, 2018).

Presentations, teamwork, quizzes, calculating individual progress scores, and group appreciation are all part of the STAD model, which has a lot of promise in the learning process. Because the learning result scores are constantly calculated and compared to the baseline score, students can identify their learning shortcomings. Low-scoring students will be pushed to study more in order to improve their individual scores. According to the STAD model, increasing language skills, creating interactive and entertaining classes, and motivating students to be more active in the learning process are all very beneficial (Firnanda et al., 2019). The lecturers' rewards for learning are what distinguishes the STAD approach. Each member of the group must be capable of giving the best to the group. Students with low abilities must be able to follow students with high abilities in order to contribute points to their group because the reward is only given to the best group with the highest score. Each individual is willing a score. Individual scores are added together to form a group score. The best group is the one with the highest score. The exercises are not just about collecting scores; they are also about how the results might reveal the character of each individual. The ultimate purpose of learning poetry is for students to comprehend the physical form and inner structure of poetry through reading various titles and poems, as well as numerous 
poetry anthologies. Finally, students were able to not only understand and recite poetry, but also interpret it.

Because of its power in reading comprehension, the CIRC model, like the STAD model, is particularly helpful in the learning process of poetry. Students with reading difficulties can be motivated to learn because the teacher serves as a facilitator throughout the process, guiding students as they comprehend the materials. All of these activities contribute to higher student learning quality. The CIRC model has been shown to benefit students' language abilities, social skills, and reading comprehension (D P Yanda et al., 2019). The CIRC model is distinctive in that it pays close attention to students' reading interests. Before beginning the session, the lecturer must determine the students' reading interests in order to divide them into groups and encourage them to think critically. Students who have a high level of interest in reading encourage students who have a low level of interest in reading to boost their reading enthusiasm.

Students who have a strong interest in reading are taught how to work together and respect students who have a weak interest in reading. Students who have a low reading interest are also taught to accept criticism and suggestions from students who have a high reading interest, and to seek to emulate the learning methods of students with a high reading interest. The second stage, namely writing collaborative results on the reading in the form of a short essay, is heavily influenced by the collaboration that takes place. In this scenario, students work in pairs to comprehend the poem before writing down the joint outcomes in the form of short essays on their own. The short essay offers the students' interpretations of the poetry's meaning.

Students collaborate and correct each other's mistakes and errors during the writing stage to ensure that the final product fits the criteria, particularly in terms of grammatical and mechanical accuracy (Ginting, 2017). The CIRC model's learning activities include a sequence of cognitive activities that allow students to reconstruct subject matter and store their information in long-term memory (Ristanto et al., 2018). Students can grasp many genres of poetry with diverse titles since it includes a sequence of cognitive activities. Because the necessary efforts are retained in their long-term memory, they become accustomed to comprehending and interpreting poetry, and appreciating poetry has become part of the routine to them.

Because the STAD and CIRC models are both student-centered learning models, the teacher acts as a facilitator when implementing poetry learning. Students are obliged to work together and assist one another in order to attain learning goals in cooperative groups. The better the teacher's application of each stage of this model, especially in studying poetry, the better the effect it will have on the process and student learning outcomes.

\section{CONCLUSION}

The STAD and CIRC models can be used to teach poetry. Both learning models are built around the idea of student-centered learning. Students assist one another in understanding and achieving learning objectives, especially when learning poetry. The teacher serves as a facilitator in the learning process, ensuring that students are able to complete each step of learning without difficulties. Both of these learning models are deemed helpful in learning poetry. The teacher's award as a form of appreciation for student performance is the STAD model's 
distinguishing feature. The reward is intended to encourage group learning collaboration depending on the outcomes. Furthermore, the CIRC model is distinctive in that it divides groups based on levels of reading interest. Before beginning the class, the teacher determines each student's level of interest in reading by administering tests prior to implementing the CIRC model.

\section{ACKNOWLEDGEMENT}

This paper was presented at the International Seminar of Language, Literature, and Education (ISLLE-1) on July 25-26, 2017 at the Grand Cempaka Hotel in Jakarta, but it was not included in the proceedings. The authors would like to express their gratitude to students of the Indonesian Language Education and Literature Study Program, STKIP PGRI in West Sumatera, Indonesia, who served as research subjects, as well as the ILEAL Journal Team (Indonesian Language Education and Literature) for their willingness to review and publish this article.

\section{REFERENCES}

Afrinda, P. D., \& Yanda, D. P. (2019). Stad Strategies of Defending Self Image in the Public Speaking Delivered by Mr Tourism Sumatera Barat. Prasasti: Journal of Linguistics, 4(1), 55-68.

Astuti, D. S. (2014). The Effectiveness of Cooperative Integrated Reading and Composition (CIRC) Method in Teaching Reading Skill Viewed From Students'Interest. Jurnal Pendidikan Bahasa, 3(1), 73-88.

Dewi, L. M. S., Wibawa, I. M. C., \& Agustiana, G. A. T. (2020). Improving Science Learning Outcomes Through Student Team Achievement Division (STAD). International Journal of Elementary Education, 4(3), 329. https://doi.org/10.23887/ijee.v4i3.25917

Eneogu, N. D., Ejimonye, J. C., Ugwuanyi, B. E., \& Nji, I. A. (2019). Comparison of Student Team Achievement Division and Team Accelerated Instruction on Student's Achievement in Secondary School Quantitative Economics Contents. Journal of Engineering and Applied Sciences, 14(5), 8912-8920.

Erly, E. (2020). Cooperatve Learning Mpdel Student Team Achievement Division (STAD) Type: The Impact of Student's Learning Motivation. Indonesian Journal of Science and Mathematics Education, 3(1), 1-8. https://doi.org/10.24042/ijsme.v3i1.5960

Firnanda, R., Gani, S. A., \& Samad, I. A. (2019). The Influence of Student TeamAchievement Divisions (STAD) in Developing Students' Speaking Skill. English Education Journal (EEJ), 10(1), 46-66.

Garcha, P. S. (2019). Effectiveness of Student Team Achievement Division (STAD) on Achievement of Secondary School Students. Indian Streams Research Journal, 6(4), 1-6. https://doi.org/10.13140/RG.2.2.24935.09121

Ginting, D. R. B. (2017). The Implementation of Cooperative Integrated Reading and Composition Strategy to Improve the Students' Ability in Reading Comprehension. Advances in Social Science, Education and Humanities Research., 1(1), 113-117. https://doi.org/10.32934/jmie.v1i1.28

Jamaludin, M., \& Mokhtar, M. F. (2018). Students Team Achievement Division. International Journal of Academic Research in Bussiness and Social Sciences, 8(2), 570-577. https://doi.org/10.6007/IJARBSS/v8-i2/3966

Khuzaemah, E., \& Herawati, L. (2017). Pembelajaran Menulis Esai Menggunakan 

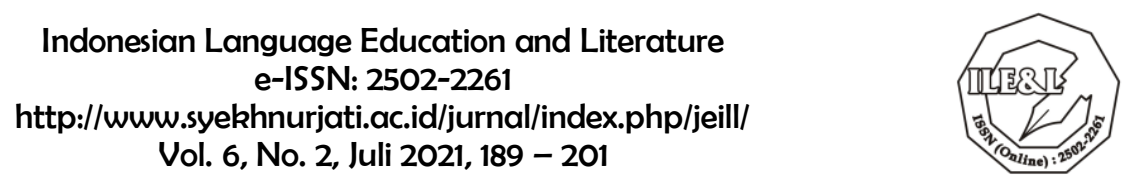

Model Cooperative Integrated Reading and Composition (CIRC) Berbasis Life Skills. Journal Indonesian Language Education and Literature, 2(2), $148-162$.

Lantajo, J. T., \& Tipolo, R. L. (2019). Student-Team Achievement Division (STAD) and Its Effect on the Academic Performance of Grade 8 Students. Journal of Physics: Conference Series, 1254(1), 1-6. https://doi.org/10.1088/1742-6596/1254/1/012014

Martono, M., Purwanti, E., Syukri, M., \& Soeharto, S. (2019). Improving The Reading Comprehension Ability by Applying the Cooperative Integrated Reading and Composition (CIRC). International Journal of Mechanical Engineering and Technology (IJMET), 10(03), 828-836.

Mulyaningsih, I. (2015). Sastra Anak: Pengembangan Kreativitas melalui Puisi dan Pantun. Cirebon: Nurjati Press.

Nafisah, J. (2018). The Effectiveness of Cooperative Integrated Reading and Composition (CIRC) Technique in Teaching Reading Comprehension on Hortatory Exposition Text. Jurnal Edulingua, 5(2), 29-40.

Nurhuda. (2020). Improving Students' Engagement in Reading Class By Using Student Teams-Achievement Division (STAD). Journal of English Education Literature, 1(2), 68-75.

Parmawati, A. (2015). The Effectiveness of Cooperative Integrated Reading and Composition (CIRC). ELTIN Journal, 3(2), 63-71.

Primasari, Y. (2018). The Effectiveness of Student Teams Achievement Division (STAD) in Teaching Reading Comprehension of the First Semester Students of English Language Education Study Program. JARES (Journal of Academic Research and Sciences), 3(2), 41-48. https://doi.org/10.35457/jares.v3i2.504

Qamariah, H., Rosdina, \& Fitri, N. (2019). Cooperative Integrated Reading and Composition Technique: A Mean of Improving Students' Ability in Writing Explanation Text. Getsempena English Education Journal (GEEJ), 6(2), 191-199.

Rahayu, E., Rohmadi, M., \& Andayani, A. (2018). Meningkatkan Minat dan Kemampuan Menulis Puisi. Indonesian Language Education and Literature, 3(2), 123-130. https://doi.org/10.24235/ileal.v3i2.1575

Ramadhanti, D. (2017). Penerapan Model Kooperatif Tipe CIRC dalam Pembelajaran Menulis Narasi Siswa Kelas VII SMP Negeri 2 Lembah Gumanti. Gramatika, 3(1), 27-42. https://doi.org/10.22202/JG.2017.V3i1.1230

Ramadhanti, D., \& Yanda, D. P. (2018). Understanding Poetry Through the Use of Cooperative Learning Model. Cakrawala Pendidikan, XXXVII(3), 436-446. https://doi.org/10.21831/cp.v38i3.20675

Ristanto, R. H., Zubaidah, S., Amin, M., \& Rohman, F. (2018). The Potential of Cooperative Integrated Reading and Composition in Biology Learning at Higher Education. International Journal of Educational Research Review, $3(1), 50-56$.

Sari, A. W., \& Yanda, D. P. (2016). Kontribusi Minat Baca Puisi dan Penguasaan Gaya Bahasa terhadap Keterampilan Menulis Puisi Bebas Siswa Kelas IX SMP Negeri 2 Lembah Gumanti. Jurnal Gramatika: Jurnal Penelitian Pendidikan Bahasa Dan Sastra Indonesia, 2(2), 179-193. https://doi.org/10.22202/JG.2016.v2i2.1087

Sepriyanti, N., Kustati, M., \& Sabri, A. (2019). Utilization Of Students Team 
Achievement Division And Team Game Tournament: Effective Ways To Increase Students' Mathematics Ability. International Journal of Scientific \& Technology Reasearch, 8(04), 80-85.

Syafiq, A. N., \& Rahmawati, A. (2017). The Effect of Student Team Achievement Division Cooperative Learning (STAD CL) in Teaching the Reading Comprehension. Refleksi Edukatika : Jurnal Ilmiah Kependidikan, 7(2), 118122. https://doi.org/10.24176/re.v7i2.1220

Syahidi, A. A., Asyikin, A. N., \& Asy'ari. (2018). Applying Student Team Achievement Divisions ( STAD ) Model on Material of Basic Programme Branch Control Structure to Increase Activity and Student Result Related content Applying Student Team Achievement Divisions (STAD) Model on Material of Basic Prog. IOP Conference Series: Materials Science and Engineering, 336, 1-9. https://doi.org/10.1088/1757-899X/336/1/012027

Thresia, F. (2012). The Contribution of Students Team Achievement Division (STAD) and Motivation Towards Writing (The Students of Enginering Faculty Muhammadiyah University of Metro). 1(2), 123-132.

Ugwu, E. O. (2019). Effect of Student Teams Achievement Division and ThinkPair-Share on Students' Achievement in Reading Comprehension. African Journal of Teacher Education, 8(1), 218-237.

Ulya, C., Wardani, N. E., \& Mujiyanto, Y. (2016). Muatan Pendidikan Antikorupsi dalam Mata Kuliah Pengkajian dan Apresiasi Puisi di Jawa Tengah dan Yogyakarta. Journal Indonesian Language Education and Literature, 2(1), 60-75.

Yanda, D. P., Ramadhanti, D., Afrinda, P. D., Bahardur, I., \& Ihsan, M. K. (2019). The Potential of Circ's Model in Poetry Learning at Higher Education. ICEL 2019, March 23-24, Malang, Indonesia. https://doi.org/10.4108/eai.23-32019.2284977

Yanda, D. P. (2018). Effect of Cooperative Learning Model Type Student Team Achievement Division ( STAD ) on Skill Understanding Poetry. Sixth Int. Conf. Lang. Arts (ICLA 2017), 148(Icla 2017), 403-407.

Yuliani, N. (2019). The Role of Student Teams Achievement Divisions (STAD) in Improving Student's Learning Outcomes. Classroom Action Research Journal, 3(1), 8-15. https://doi.org/10.17977/um013v3i12019p008

Zainuddin. (2015). The Effect of Cooperative Integrated Reading and Composition Technique on Students' Reading Descriptive Text Achievement. English Language Teaching, 8(5), 11-21. https://doi.org/10.5539/elt.v8n5p11 